\title{
Screening of Genotypes on Basis of Chlorophyll Content, Nitrate Reductase Activity and Kernel Yield in Groundnut (Arachis hypogaea L.)
}

\author{
Mohammed Anwar Ali' ${ }^{*}$, Anjan Kumar Pal', Apurba Pal', \\ Ananya Baidya ${ }^{2}$ and Sunil Kumar Gunri ${ }^{3}$
}
${ }^{1}$ Department of Crop Physiology, Acharya N.G. Ranga Agricultural University, Agricultural College Bapatla, Andhra Pradesh - 522101, India
${ }^{2}$ Department of Plant Physiology, ${ }^{3}$ Department of Agronomy, F/Ag, Bidhan Chandra Krishi Viswavidyalaya, Nadia, West Bengal - 741252, India

*Corresponding author

\section{A B S T R A C T}

\section{Keywords \\ Groundnut, Chlorophyll content, Nitrate reductase activity and Kernel yield \\ Article Info \\ Accepted: \\ 26 August 2018 \\ Available Online: \\ 10 September 2018}

\begin{abstract}
Nineteen groundnut genotypes were screened for physiological characters, chlorophyll content and nitrate reductase activity at 30 DAS (pre-anthesis) and 60 DAS (post-anthesis) along with kernel yield during the Pre-summer. Leaf chlorophyll content and nitrate reductase activity plays a considerable role in plant metabolism. Nitrate reductase is one of the most important enzymes in the assimilation of exogenous nitrate, the predominant form of nitrogen available to green plants growing in soil, helps in maintaining the plant photosynthetic machinery, which in turn results in accumulation of metabolites for storage i.e., kernel yield. High significant differences were observed in genotypes for chlorophyll content and nitrate reductase activity in relation to kernel yield.
\end{abstract}

\section{Introduction}

Groundnut (Arachis hypogaea $\quad$ L.) is considered as one of the most important legume and oil seed crops, which is valued not only for edible oil and protein for human beings but also as fodder for livestock (Sharma and Sardana, 2012). Bently Glass (1961) aptly stated, "Life is a photochemical phenomenon." The chemical compounds most important in conversion of light energy into chemical energy are the pigments that exist within the chloroplast/chromatophores of plant. The chlorophylls, the green pigment of the chloroplast, are the most important photosynthetic plant pigments. In groundnut (water use efficiency) is governed by the photosynthetic capacity which is dependent on leaf nitrogen status. Leaf nitrogen status is ultimately reflected in chlorophyll content (Vasanthi et al., 2005).

Nitrate reductase (NR), the first in the series of enzymes that reduces nitrogen to ammonia. NR is a metalloflavo protein inducible enzyme which catalyses the reduction of nitrate to 
nitrite. It acts as a rate limiting step and regulatory enzyme in the pathway i.e., $\mathrm{NO}_{3}{ }^{-}$to $\mathrm{NO}_{2}{ }^{-}$, and its activity often controls the assimilation rate of nitrate.

Out of two different pools for nitrate in plant tissues i.e., storage and metabolic pools, only nitrate of the metabolic pool functions as a substrate for NR and contributes to organic nitrogen.

Increase in the chlorophyll content and nitrate reductase activity could improve the yield of plants. The present experiment carried out to find such genotypes, which poses higher chlorophyll content, nitrate reductase activity and high kernel yield.

\section{Materials and Methods}

The field experiment was conducted in Incheck Farm, 'C' Block, BCKV, Kalyani, Nadia. The soil texture of the experimental plot was sandy loam with $\mathrm{pH}$ 6.9-7.0. Nineteen genotypes of groundnut were subjected to yield trial in the year 2015 (Presummer). The genotypes collected from AICRP on Groundnut, BCKV, Kalyani, India.

The design of the experiment was randomized block design (RBD), replicated thrice. A uniform spacing of $30 \mathrm{~cm}$ row to row and 15 $\mathrm{cm}$ plant to plant was followed in each case. Appropriate plant protection measures along with other standard cultural practices were followed to raise a healthy crop.

Physiological traits such as, i. Chlorophyll content of leaf ( $\mathrm{mg} \mathrm{g}^{-1}$ fresh weight), ii. Nitrate reductase activity in leaves ( $\mathrm{mM}$ nitrite formed hour ${ }^{-1} \mathrm{~g}^{-1}$ fresh weight) were estimated from the leaf sample collected at 30 and 60 days after sowing (DAS) in each genotype. Kernel yield were taken from five (5) randomly selected plants per replicate for each of the genotype.

\section{Estimation of chlorophyll}

The chlorophyll content in the leaf sample was estimated as per Arnon (1949), at 30 DAS (pre-anthesis) and 60 DAS (post-anthesis). Further chlorophyll 'a' (chl. 'a'), chlorophyll 'b' (chl. 'b'), total chlorophyll and chlorophyll 'a'/chlorophyll 'b' (chl. 'a'/chl. 'b') were calculated as per formulae in the method.

mg of chlorophyll ' $\mathrm{a}$ '/g of fresh tissue $=[(12.7$ $\left.\left.\mathrm{x} \mathrm{A}_{663}\right)-\left(2.69 \times \mathrm{A}_{645}\right)\right] \times[\mathrm{V} / 1000 \times \mathrm{W}]$

$\mathrm{mg}$ of chlorophyll ' $\mathrm{b}$ '/g fresh tissue $=[(22.9 \mathrm{x}$ $\left.\left.\mathrm{A}_{645}\right)-\left(4.68 \times \mathrm{A}_{663}\right)\right] \times[\mathrm{V} / 1000 \times \mathrm{W}]$

$\mathrm{mg}$ of total chlorophyll/g of fresh tissue = $\left[\left(20.2 \times \mathrm{A}_{645}\right)+\left(8.02 \times \mathrm{A}_{663}\right)\right] \times[\mathrm{V} / 1000 \times \mathrm{W}]$

Where, $\mathrm{V}=$ Volume of the extract $(\mathrm{ml}), \mathrm{W}=$ Fresh weight of tissue (g), A = Absorbance.

\section{Measurement of nitrate reductase activity}

Extraction of nitrate reductase (NR) and the estimation of enzyme activities in leaves was assayedas per Jaworski (1971), at 30 DAS (pre-anthesis) and 60 DAS (post-anthesis). NR activity is expressed as $\mathrm{mM}$ nitrite formed hour $^{-1} \mathrm{~g}^{-1}$ fresh weight.

\section{Statistical analysis}

The mean data on pod yield were subjected to statistical analysis following randomized block design (RBD) by INDOSTAT version 7.1 software. Least Significant Difference (LSD) at $\mathrm{P} \leq 0.05$ statistically compared the mean values.

\section{Results and Discussion}

The content of chlorophyll 'a', chlorophyll 'b', chlorophyll ' $a$ '/‘b' as well as total chlorophyll and the activity of nitrate reductase enzyme in the leaf of nineteen 
genotypes were assayed at 30 and 60 DAS. The analysis of variance exhibited highly significant variation among the genotypes for these physiological characters.

\section{Leaf chlorophyll content}

The content of chlorophyll ' $a$ ', chlorophyll ' $b$ ' and total chlorophyll in the leaves of nineteen genotypes of groundnut furnished in (Table 1) at 30 DAS varied from 0.98-1.41, 0.41-0.61 and $1.43-1.89 \mathrm{mg} \mathrm{g}^{-1}$ fresh weight of leaf, respectively. The genotype INS-1-2013-8 and INS-1-2013-6 recorded the highest content of leaf chlorophyll among all the genotypes at this growth stage (30 DAS). INS-1-2013-8 also had the highest content of chlorophyll ' $a$ ' (1.41), total chlorophyll (1.89) and chlorophyll 'a'/'b' (2.94 mg g $\left.{ }^{-1}\right)$ respectively. The mean values for chlorophyll ' $a$ ', chlorophyll ' $b$ ' and total chlorophyll in the leaves of nineteen genotypes of groundnut at 60 DAS ranged from $0.10-1.26,0.28-0.53$ and $1.16-1.77 \mathrm{mg}$ $\mathrm{g}^{-1}$ fresh weight of leaf, respectively. Out of all the genotypes, INS-1-2013-8 registered the highest mean for these three characters.

It might be noted that this genotype also recorded the highest kernel yield. However, in the present experiment, the ratio of chlorophyll ' $a$ ' to chlorophyll ' $b$ ' ranged from 1.99-2.94 and from $2.22-3.38$ at 30 and 60 DAS, respectively. Perusal of the data further indicated that the chlorophyll content in all the genotypes except one (INS-1-2013-5) decreased at 60 DAS as compared to 30 DAS. This might indicate the onset of leaf senescence at the time of post-flowering remobilization of photo-assimilates.

\section{Nitrate reductase activity}

Nitrate reductase (NR) catalyses the reduction of nitrate to nitrite, which is the first step in assimilation of nitrate absorbed by the roots into organic compounds in plants. It is an important enzyme in nitrogen metabolism of the plants. The mean values presented in (Table 2) indicates that the activity of nitrate reductase in the leaf at 30 and 60 DAS ranged from 1.56-4.68 mM nitrite formed hour ${ }^{-1} \mathrm{~g}^{-1}$ fresh weight and from 1.25-2.65 $\mathrm{mM}$ nitrite formed hour ${ }^{-1} \mathrm{~g}^{-1}$ fresh weight at 30 and 60 DAS, respectively. The genotype INS-1-201326 registered the highest activity of NR in leaf at both the growth stages 4.68 and $2.65 \mathrm{mM}$ nitrite formed hour ${ }^{-1} \mathrm{~g}^{-1}$ fresh weight at 30 and 60 DAS respectively, whereas INS-1-2013-9 recorded the lowest mean 1.56 and $1.25 \mathrm{mM}$ nitrite formed hour ${ }^{-1} \mathrm{~g}^{-1}$ fresh weight at 30 and 60 DAS respectively.

The pattern of changes further indicated that the NR activity in the leaf reduced at 60 DAS in comparison with that at $30 \mathrm{DAS}$ in all the genotypes except in INS-1-2013-2, which showed slight increase. These results are in line with the results of Sung and sun, 1990. Thus, the activity of nitrate reductase enzyme was found to be higher in pre-anthesis stage than in post-anthesis pod filling stage. It might be concluded that the plants mainly depended on the remobilization of nitrogen reserve during pod filling stage as indicated by the results in the present experiment. The observation was more or less consistent with the early finding of Thibodeau and Jaworski, (1975) reported a drop in nitrate reductase activity in soybean leaves during postflowering stage.

\section{Kernel yield}

The mean values for kernel yield per plant (Figure 1) ranged from $6.85 \mathrm{~g}$ to $17.22 \mathrm{~g}$. Among all the genotypes, INS-1-2013-8 registered the highest kernel yield (17.22 g) and it was followed by INS-1-2013-5 (15.55 g) and INS-1-2013-4 (13.13 g). The genotype INS-1-2013-1 had the lowest kernel weight per plant $(6.85 \mathrm{~g})$ and it was followed by INS1-2013-7 (7.71 g). 
Table.1 Chlorophyll content in the leaves of nineteen genotypes of Groundnut ( $\mathrm{mg} \mathrm{g}^{-1}$ fresh weight)

30 DAS

60 DAS

\begin{tabular}{|c|c|c|c|c|c|c|c|c|}
\hline Genotypes & $\begin{array}{l}\text { Chloroph } \\
\text { yll - 'a' }\end{array}$ & $\begin{array}{l}\text { Chlorophy } \\
\text { ll -'b' }\end{array}$ & $\begin{array}{c}\text { Total } \\
\text { Chlorophy } \\
\text { ll }\end{array}$ & $\begin{array}{c}\text { Chlorophy } \\
\text { ll } \\
\text { 'a'/'b' }\end{array}$ & $\begin{array}{c}\text { Chlorophy } \\
\text { ll-'a' }\end{array}$ & $\begin{array}{l}\text { Chlorophy } \\
\text { ll-'b' }\end{array}$ & $\begin{array}{c}\text { Total } \\
\text { Chlorophy } \\
\text { Il }\end{array}$ & $\begin{array}{c}\text { Chlorophy } \\
\text { ll } \\
\text { 'a'/‘b' }\end{array}$ \\
\hline INS-1-2013-1 & 1.22 & 0.61 & 1.83 & 1.99 & 0.86 & 0.29 & 1.16 & 2.93 \\
\hline INS-1-2013-2 & 1.15 & 0.43 & 1.58 & 2.70 & 0.87 & 0.30 & 1.17 & 2.94 \\
\hline INS-1-2013-3 & 1.17 & 0.53 & 1.70 & 2.23 & 0.98 & 0.33 & 1.30 & 2.97 \\
\hline INS-1-2013-4 & 0.98 & 0.45 & 1.43 & 2.20 & 1.00 & 0.33 & 1.33 & 3.03 \\
\hline INS-1-2013-5 & 1.12 & 0.55 & 1.67 & 2.05 & 1.26 & 0.41 & 1.67 & 3.08 \\
\hline INS-1-2013-6 & 1.30 & 0.54 & 1.84 & 2.40 & 1.05 & 0.39 & 1.44 & 2.72 \\
\hline INS-1-2013-7 & 1.05 & 0.46 & 1.51 & 2.28 & 1.05 & 0.36 & 1.41 & 2.93 \\
\hline INS-1-2013-8 & 1.41 & 0.48 & 1.89 & 2.94 & 1.24 & 0.53 & 1.77 & 2.35 \\
\hline INS-1-2013-9 & 1.21 & 0.42 & 1.63 & 2.88 & 1.12 & 0.45 & 1.56 & 2.57 \\
\hline $\begin{array}{l}\text { INS-1-2013- } \\
10\end{array}$ & 1.28 & 0.47 & 1.75 & 2.73 & 1.23 & 0.42 & 1.65 & 2.90 \\
\hline $\begin{array}{l}\text { INS-1-2013- } \\
11\end{array}$ & 1.10 & 0.45 & 1.54 & 2.50 & 0.91 & 0.41 & 1.32 & 2.22 \\
\hline $\begin{array}{l}\text { INS-1-2013- } \\
12\end{array}$ & 1.19 & 0.48 & 1.67 & 2.47 & 1.03 & 0.38 & 1.41 & 2.74 \\
\hline $\begin{array}{l}\text { INS-1-2013- } \\
13\end{array}$ & 1.32 & 0.50 & 1.81 & 2.70 & 1.12 & 0.44 & 1.57 & 2.54 \\
\hline $\begin{array}{l}\text { INS-1-2013- } \\
23\end{array}$ & 1.30 & 0.50 & 1.81 & 2.59 & 1.13 & 0.40 & 1.54 & 2.84 \\
\hline $\begin{array}{l}\text { INS-1-2013- } \\
26\end{array}$ & 1.05 & 0.41 & 1.47 & 2.53 & 1.10 & 0.34 & 1.43 & 3.28 \\
\hline $\begin{array}{l}\text { INS-1-2013- } \\
28\end{array}$ & 1.17 & 0.53 & 1.70 & 2.21 & 0.10 & 0.40 & 1.40 & 2.50 \\
\hline $\begin{array}{l}\text { INS-1-2013- } \\
33\end{array}$ & 1.28 & 0.50 & 1.70 & 2.55 & 0.99 & 0.41 & 1.39 & 2.44 \\
\hline $\begin{array}{l}\text { INS-1-2013- } \\
34\end{array}$ & 1.14 & 0.46 & 1.60 & 2.48 & 1.06 & 0.32 & 1.38 & 3.38 \\
\hline $\begin{array}{l}\text { INS-1-2013- } \\
35\end{array}$ & 1.26 & 0.53 & 1.78 & 2.39 & 0.90 & 0.28 & 1.18 & 3.37 \\
\hline S.E. $(\mathrm{m}) \pm$ & 0.072 & 0.036 & 0.080 & 0.241 & 0.077 & 0.026 & 0.080 & 0.304 \\
\hline $\begin{array}{l}\text { C.D. } \\
(P=0.05)\end{array}$ & 0.147 & 0.073 & 0.163 & 0.490 & 0.156 & 0.054 & 0.162 & 0.616 \\
\hline
\end{tabular}

(DAS= Days After Sowing) 
Table.2 Nitrate reductase activity in the leaves of nineteen genotypes of groundnut (data expressed as $\mathrm{mM}$ nitrite formed hour ${ }^{-1} \mathrm{~g}^{-1}$ fresh weight)

\begin{tabular}{|l|c|c|}
\hline \multirow{2}{*}{ Genotypes } & \multicolumn{2}{|c|}{ NR activity } \\
\hline INS-1-2013-1 & 30 DAS & 60 DAS \\
\hline INS-1-2013-2 & 2.28 & 2.17 \\
\hline INS-1-2013-3 & 1.99 & 2.02 \\
\hline INS-1-2013-4 & 3.73 & 1.30 \\
\hline INS-1-2013-5 & 1.92 & 1.30 \\
\hline INS-1-2013-6 & 3.48 & 1.29 \\
\hline INS-1-2013-7 & 3.25 & 1.65 \\
\hline INS-1-2013-8 & 3.90 & 1.45 \\
\hline INS-1-2013-9 & 1.56 & 1.35 \\
\hline INS-1-2013-10 & 2.77 & 1.25 \\
\hline INS-1-2013-11 & 2.81 & 2.52 \\
\hline INS-1-2013-12 & 2.85 & 2.18 \\
\hline INS-1-2013-13 & 2.44 & 2.10 \\
\hline INS-1-2013-23 & 2.84 & 2.61 \\
\hline INS-1-2013-26 & 4.68 & 2.06 \\
\hline INS-1-2013-28 & 3.22 & 2.45 \\
\hline INS-1-2013-33 & 2.56 & 2.10 \\
\hline INS-1-2013-34 & 2.98 & 1.88 \\
\hline INS-1-2013-35 & 3.66 & 2.54 \\
\hline S.E. (m) & 0.207 & 0.208 \\
\hline C.D. (P=0.05) & 0.420 & 0.421 \\
\hline NR-N & & \\
\hline
\end{tabular}

(DAS-Days After Sowing, NR-Nitrate Reductase)

Fig.1 Kernel yield in nineteen genotypes of groundnut

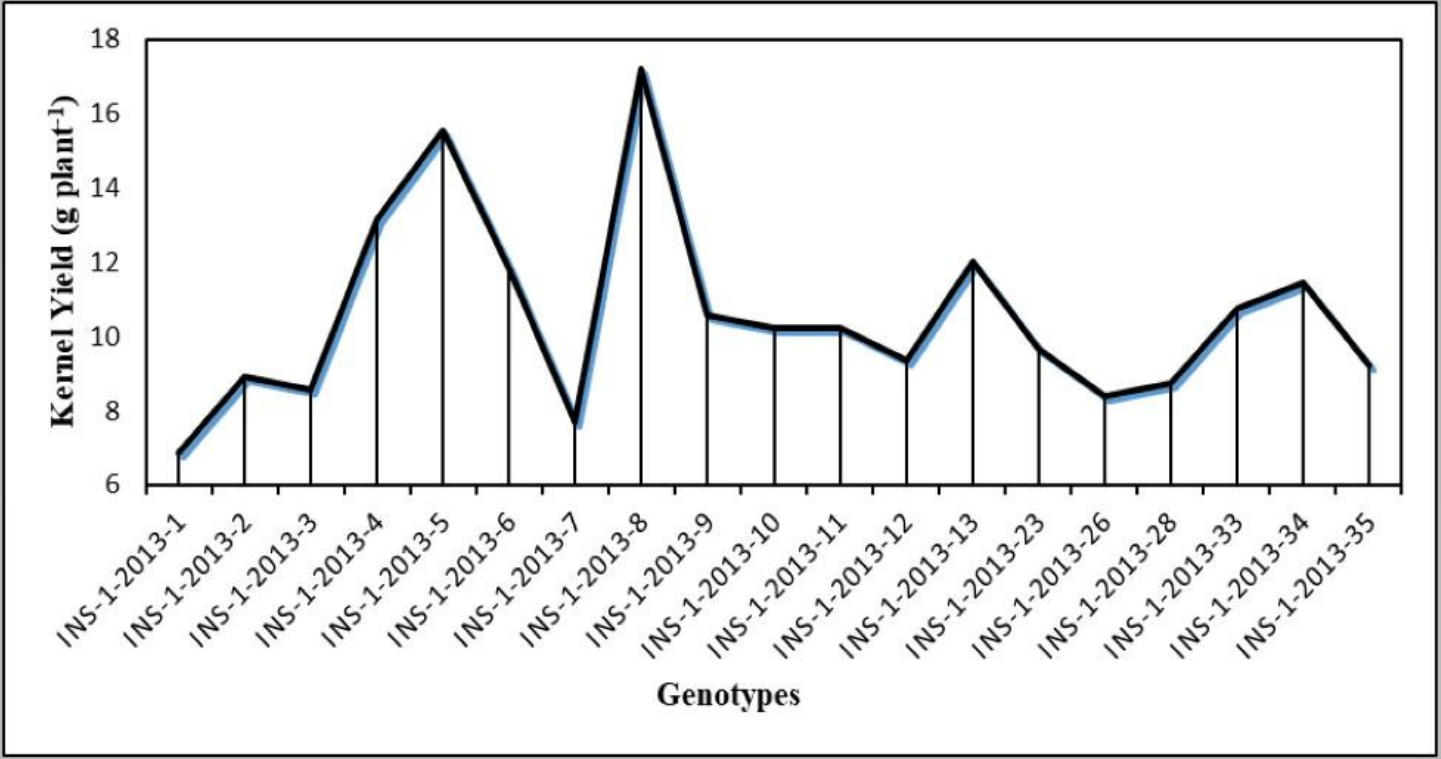


The genotypes showed significant differences among them in respect of kernel yield and its all attributes. Three genotypes, INS-1-2013-8, INS-1-2013-5 and INS-1-2013-4 were the top ranking genotypes in respect of kernel yield/plant. The leaf chlorophyll content as well as the nitrate reductase activity of leaf decreased at post-anthesis pod filling stage as compared to pre-anthesis stage. Thus, the genotypes mainly depended on remobilization of nitrogen reserve and photo-assimilates during pod filling stage rather than current photosynthetic and nitrogen assimilation activity.

\section{Acknowledgement}

Authors are grateful to AICRP on Groundnut, Kalyani, India, for providing genotypes. Author is also thankful to Dr. Sunil Kumar Gunri for extending the facilities at field.

\section{References}

Arnon, D.I. 1949. Copper enzyme in isolated chloroplast polyphenol oxidase in Beta vulgaris. Plant Physiology.24: 1-15.
Glass, B. 1961. In summary, A symposium on light and life. John Hopkins press, Baltimore. 817-912.

Jaworski, E.G. 1971. Nitrate reductase assay in intact plant tissues. Biochemical and Biophysical Research Communications. 43: 1274-1279.

Sharma, P and Sardana, V. 2012. Effect of growth regulating substances on the chlorophyll, nitrate reductase, leghaemoglobin content and yield in groundnut (Arachis hypogaea L.). The Bioscan. 7(1): 13-17.

Sung, F.J.M and Sun, Y.W. 1990. Seasonal patterns of nitrate reductase and nitrogenase activities in Arachis hypogaea. Field Crops Research.25: 215-222.

Thibodeau, P.S and Jaworski, E.G. 1975. Patterns of nitrogen utilization in the soybean. Planta. 127: 133-147.

Vasanthi, R.P., Sreelatha Devi, G., Babitha, $M$ and Sudhakar, P. 2005. Inheritance of leaf chlorophyll content in groundnut (Arachis hypogaea L.). Indian Journal of Genetics. 65(3): 196-198.

\section{How to cite this article:}

Mohammed Anwar Ali, Anjan Kumar Pal, Apurba Pal, Ananya Baidya and Sunil Kumar Gunri. 2018. Screening of Genotypes on Basis of Chlorophyll Content, Nitrate Reductase Activity and Kernel Yield in Groundnut (Arachis hypogaea L.). Int.J.Curr.Microbiol.App.Sci. 7(08): 4645-4650. doi: https://doi.org/10.20546/ijcmas.2018.708.490 